\title{
Population Briefs, Vol. 15, no. 1
}

Population Council

Follow this and additional works at: https://knowledgecommons.popcouncil.org/ series_newsletters_popbriefs How does access to this work benefit you? Let us know!

\section{Recommended Citation}

Population Briefs 15(1): New York: Population Council, 2009. 


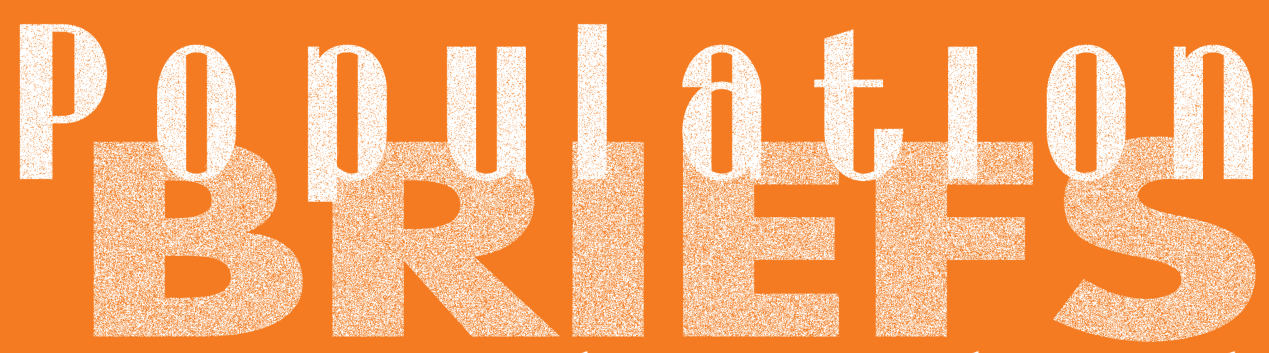

Reports on Population Council Research

July 2009 Volume 15, Number 1

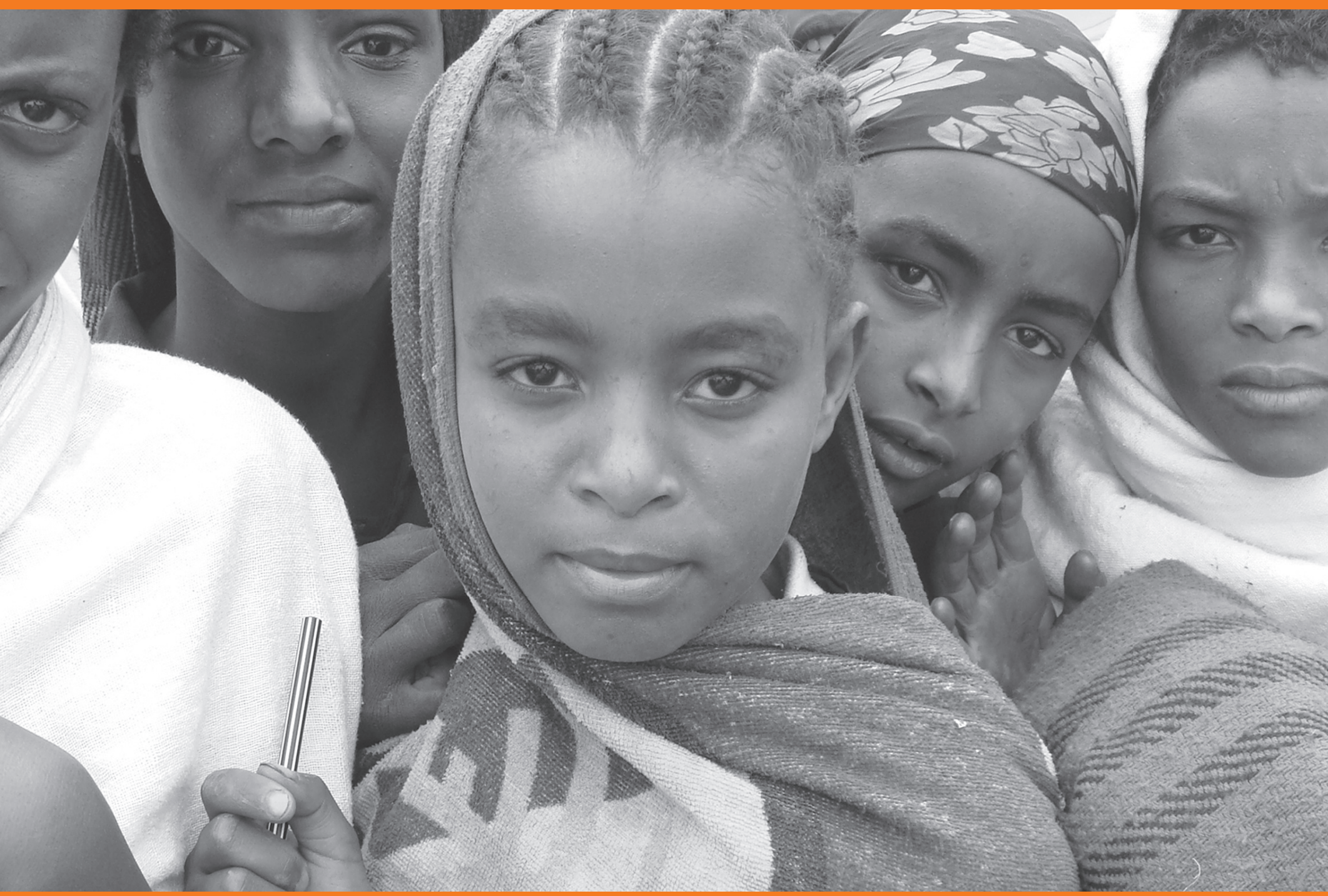

A Population Council program in rural Amhara, Ethiopia

reduced child marriage among girls aged 10-14 by 90 percent.

See story, page 4.

\section{NS I DE}

Abortions in Mexico Increased by a Third in 16 Years ........2 Study Finds Link between Phthalates and

Low Birth Weight.

3

Program Shown to Significantly Delay Child Marriage........ 4

Family Planning Programs Remarkably Successful............. 6

Recent Publications.

. .7

Trial Showed Anti-HIV Microbicide Candidate Is Safe, but Did Not Prove It Effective... 


\section{Abortions in Mexico Increased by a Third in 16 Years}

A national study shows that the number of abortions performed in Mexico increased by one-third between 1990 and 2006, despite stateby-state legal restrictions that virtually ban the procedure in most parts of the country. (In 2007, watershed legislation was passed in Mexico City permitting the interruption of first-trimester pregnancies in the Federal District.) The study, conducted by Sandra G. García, the Population Council's country director for Mexico, and colleagues at El Colegio de México, the Guttmacher Institute, and Mexico's National Institute of Public Health, found that many abortions in Mexico take place under unsafe conditions, resulting in serious health consequences for women.

\section{Unsafe abortion}

Unsafe abortions, those that are performed by people who lack adequate skills or occur under conditions that do not meet basic medical standards, pose a huge public health threat. Worldwide, unsafe abortion accounts for 13 percent of the more than half a million pregnancy-related deaths that occur every year. Unsafe abortion is often the only choice for women who want to end a pregnancy in a country where abortion is illegal or greatly restricted. Countries in Latin America and the Caribbean have some of the most restrictive abortion laws in the world.

Estimates of the incidence of unsafe abortion are crucial for defining the scope of the problem and developing appropriate policies. Yet, collecting accurate data on this sensitive topic is extremely difficult. Women often underreport abortion because of stigma surrounding the procedure. In the early 1990s, Susheela Singh of the Guttmacher Institute, one of the researchers on this study, and her colleague Deirdre Wulf developed a new indirect method to estimate abortion incidence in Latin America using information about hospital admissions. Since not all women who get abortions need or seek follow-up in a hospital, the method combines data about hospitalizations with information gathered from knowledgeable public health experts to extrapolate the number of induced abortions occurring each year. Using 1990 data from Mexico, Singh and Wulf estimated that 533,000 induced abortions occurred that year, and that the abortion rate was 25 per 1,000 women aged 15-44.

\section{Misoprostol}

But the 1990 figures are nearly 20 years old, and significant changes have occurred since then that might influence the incidence of abortion. Chief among these changes is the use of misoprostol as an abortifacient drug. Misoprostol, marketed as Cytotec, is approved to treat gastric ulcers. Misoprostol also can be used to induce abortion. Preliminary findings from a recent Population Council study of Mexican pharmacies suggest that misoprostol has been gaining in popularity as a means of inducing abortion.

\section{The new estimate}

To produce a new estimate of abortion incidence, the researchers updated their methodology, including changes to reflect the availability of misoprostol. They analyzed hospital discharge data, surveyed knowledgeable health professionals, and examined the results of government surveys that asked about contraceptive use, unmet need for contraception, and pregnancy intentions. The most recent data are from 2006, the year for which these estimates were made.

Taken together and using a set of assumptions, the various data sources enable investigators to calculate estimates of abortion incidence. The team estimated that in 2006, 875,000 induced abortions occurred in Mexico, and that the abortion rate was 33 per 1,000 women aged 15-44. This represents an increase of 33 percent in the abortion rate from 1990. Coauthors also calculated first-time estimates of abortion incidence for sub-regions of Mexico.

"These findings confirm research from other parts of the world - that making abor- tion illegal does not significantly decrease its frequency, it just makes it unsafe and puts women's lives at risk," said Fatima Juárez, the study's lead author and a professor at El Colegio de México and senior fellow at the Guttmacher Institute.

Lack of information on family planning and limited access to contraceptive methods may help explain why Mexican women are increasingly turning to abortion, the authors suggest. In addition, access to modern contraceptive methods in Mexico has not kept pace with women's increasing desire to have smaller families. The average number of children per family has declined dramatically over the last 30 years, decreasing from 5.6 in 1976 to 2.2 in 2006.

"In Mexico, in this last decade we've seen setbacks in terms of pregnancy prevention," notes the Council's García. "For the past several years several states have not prioritized stocking their health centers with basic contraceptives, like pills and condoms. And they are definitely not doing adequate outreach to vulnerable groups. We think there needs to be more emphasis on preventing unintended pregnancy."

To reduce the negative consequences of clandestine abortion, the researchers recommend broadening access to legal abortion beyond Mexico City to the rest of the country; improving contraceptive services, including postabortion contraceptive counseling; increasing youth-focused initiatives and school-based comprehensive sex education programs; and expanding training in safe abortion provision.

\footnotetext{
SOURCE

Juárez, Fatima, Susheela Singh, Sandra G. García, and Claudia Díaz Olavarrieta. 2008. "Estimates of induced abortion in Mexico: What's changed between 1990 and 2006?" International Family Planning Perspectives 34(4): 158-168.

OUTSIDE FUNDING

Anonymous and the William and Flora Hewlett Foundation
} 


\section{Study Finds Link between Phthalates and Low Birth Weight}

Phthalates, chemicals used to make plastics more flexible, are ubiquitous in the environment. They are found in the bottles of many personal care products; in flooring, shower curtains, and raincoats; and in medical tubing and fluid bags. They have been found to be endocrine disruptors, meaning that they can alter hormone levels in the body.

Animal studies have shown that increased exposure to phthalates is tightly linked to low birth weight in male offspring. Before now, however, there had been no studies on the effects of phthalates on birth weight in people. To address this knowledge gap, Population Council Bixby Fellow Yunhui Zhang, Council biomedical researcher Renshan Ge, and their colleagues at Fudan University and Second Military Medical University in China examined phthalate levels in 201 mother-newborn pairs in Shanghai, China to determine whether there is a link between human low birth weight and phthalates.

\section{Low birth weight}

Infants born weighing less than 2500 grams, about 5.5 pounds, are considered to be of low birth weight. Almost a quarter of all babies born worldwide, more than 30 million infants annually, weigh less than 2500 grams. These babies, particularly those in developing countries, are susceptible to postnatal complications and infections. They have a higher death rate than heavier infants. A number of factors, including malnutrition in the mother, her socioeconomic status, and her exposure to smoking or secondhand smoke, are known to contribute to low birth weight.

During 2005-06, the researchers enrolled 88 mother-newborn pairs in which the baby had low birth weight and 113 pairs in which the baby was born at a normal weight. The pairs in both groups were similar in key characteristics, such as socioeconomic status, prenatal care, and the mother's pre-pregnancy body mass index.

"Numerous studies have found that the effects of phthalates are more significant in children than adults," explained Zhang. "A fetus, because it is still in early stages of development, might have yet further susceptibility to the potentially adverse effects of phthalates."

To determine the level of phthalates

\section{"Numerous studies have}

found that the effects

of phthalates are more

significant in children

than adults. The fetus

might have increased

susceptibility to the po-

tentially adverse effects

of phthalates."

to which the infants had been exposed in utero, the researchers gathered samples of the mother's blood, blood from the umbilical cord, and all meconium from the first 48 hours after birth. Meconium, the baby's first bowel movement, begins to accumulate in the fetus at about four months into a pregnancy and is not excreted until after birth. Because it builds up throughout much of the pregnancy, meconium is a good indicator of cumulative prenatal exposure to phthalates. Phthalates are broken down relatively quickly in the blood, so the blood samples give a snapshot of recent phthalate exposure. The scientists tested the biological samples for three phthalates and two chemicals that arise when these phthalates are metabolized by the body.

They found that more than 70 percent of the samples had quantifiable levels of phthalates and phthalate metabolites. Lowbirth-weight babies had significantly higher phthalate levels than the infants who were of normal birth weight. In particular, one phthalate, known as DBP, was associated with low birth weight. A dose-response relationship was found between low birth weight and both DBP in cord blood and MBP (the metabolite of $\mathrm{DBP}$ ) in meconium. This means that the higher the exposure to DBP, the lower the infant's birth weight. Another phthalate, known as DEHP, was associated with babies being shorter than normal.

"Continued surveillance and additional research are needed to evaluate the complex potential health risks from high exposure to phthalates," said Ge.

\section{SOURCE}

Zhang, Yunhui, Ling Lin, Yang Cao, Bingheng Chen, Lixing Zheng, and Renshan Ge. "Phthalate levels and low birth weight: A nested case-control study of Chinese newborns," forthcoming in The Journal of Pediatrics (published online 25 June 2009).

\section{OUTSIDE FUNDING}

Fred H. Bixby Foundation, Natural Science Foundation of China

Miss an issue of Population Briefs? Back issues are available free of charge while supplies last.

All issues of Population Briefs are available on the Population Council's Web site: www.popcouncil.org/ publications/popbriefs/default.htm 


\section{Program Shown to Significantly Delay Child Marriage}

An innovative program designed and evaluated by the Population Council, in collaboration with government agencies in Ethiopia, has significantly reduced child marriage among young adolescent girls. (Child marriage, defined as marriage before the age of 18 , is a violation of human rights, according to many international conventions.) The program, which also substantially improved many aspects of the girls' lives, is one of the first such successes documented by rigorous research.

\section{Rural Ambara}

In the Amhara region of Ethiopia, rates of child marriage are among the highest in the world. Half of all girls in Amhara are married before their 15 th birthday, and 80 percent are married by age 18 . Girls who marry early are exposed to increased reproductive risks, experiencing sexual initiation earlier than unmarried girls as well as first births at a young age. Very early first births are associated with maternal risks, including obstructed labor that can lead to obstetric fistula.

Amhara also has high rates of divorce, with many divorced girls migrating to urban centers because of the stigma of divorce. Anecdotal evidence suggests that in order to survive, these young women often become domestic workers, involving long hours and low pay, and some, as a last option, become sex workers.

The Population Council, led by Ethiopia country director Annabel Erulkar, joined with Ethiopia's Ministry of Youth and Sport and the Amhara Regional Bureau of Youth and Sport to design and implement the Berhane Hewan program in Amhara. Berbane Hewan means "Light for Eve" in Amharic. The groups developed the program to inform community members about the dangers of child marriage, to prevent early marriage among unmarried adolescents, and to provide support for girls who are already married.

Before the start of the program, researchers conducted a survey of adolescent girls in Amhara and found:
- Ninety-five percent of the girls surveyed did not know their husband before marriage, and 85 percent were not told that they were going to be married.

- More than two-thirds of married girls reported that they had not started menstruating when they had sex for the first time.

- Not surprisingly, many of these marital unions are unstable: 12 percent of girls in Amhara aged 10-19 are already divorced.

\section{Younger girls involved}

in the program were 90

percent less likely to get

married early than girls

of the same age who did

not participate.

On the basis of these findings and the results of conversations with community members, the program was designed to use a combination of approaches:

- participation in peer groups for married and unmarried girls led by female mentors in community meeting spaces to overcome the isolation of adolescents;

- promotion of school attendance for both formal and non-formal education, such as basic literacy and livelihood skills;

- economic incentives for school attendance and delaying marriage: unmarried girls who participated in the groups and remained unmarried for the duration of the program were presented with a goat at the graduation ceremony; and

- participatory community discussion concerning early marriage, other harmful traditional practices, and reproductive health.
The Amhara Regional Bureau of Youth and Sport pilot-tested the program in Mosebo Village, Amhara region, between 2004 and 2006. The community responded enthusiastically to the program; more than 650 girls in Mosebo joined Berhane Hewan in the two-year pilot period.

Participating girls had three options for involvement in the program. Girls who were still in school were encouraged to continue their education and were given school materials, such as paper, pens, and pencils. Out-ofschool girls who wanted to return to formal school were encouraged to do so and were given the same materials. Other out-of-school girls, as well as those who never attended school, were organized into groups of married and unmarried girls of about 15-20 girls each and met regularly with mentors. Married girls, who face more time constraints than unmarried girls, met once a week; unmarried girls met five times a week.

The researchers also studied comparable girls in another area—Enamirt Village, Mecha District — where the program had not yet been launched. The researchers conducted population-based impact evaluations immediately before the implementation and again two years later, in both experimental and control areas. Researchers examined changes associated with the program by comparing characteristics of girls living in both locations before and after the pilot program. This evaluation focused on four main areas: social networks and participation, education, marital status, and reproductive health.

\section{Success!}

The evaluations showed that the vast majority of girls living in the experimental area (92 percent) had heard of the program. Eighty-five percent of them had taken part in the peer groups, and three-fourths had attended a community discussion. At the same time, no girls in the control area had heard of the program, reflecting no contamination of the control site. 
The researchers found that the lives of girls who participated in the program improved in all areas that were targeted by the program, including friendship networks, school attendance, age at marriage, reproductive health knowledge and communication, and contraceptive use.

The impact of the program was particularly apparent for younger girls, aged 10 to 14. After controlling for marital status, age, and socioeconomic status, Mosebo girls in this age group were significantly more likely to be in school than were girls in the control area. Family planning use increased in both areas, but more so in the experimental site. No statistically significant differences were found between the two communities in use of family planning methods at baseline. Among married and sexually experienced girls, those living in Mosebo were nearly three times more likely to have ever used a family planning method after the intervention. Compared to girls in the control site, girls in the program site also were significantly more knowledgeable about HIV, sexually transmitted infections, and family planning methods, and were more likely to have discussed these issues with a close friend.

\section{Child marriage}

Perhaps most strikingly, statistical analysis revealed considerable effects on the age at marriage for younger girls, aged 10 to 14 . Younger Mosebo girls were 90 percent less likely to be married than were Enamirt girls in the same age group. In addition, not one girl aged 10 to

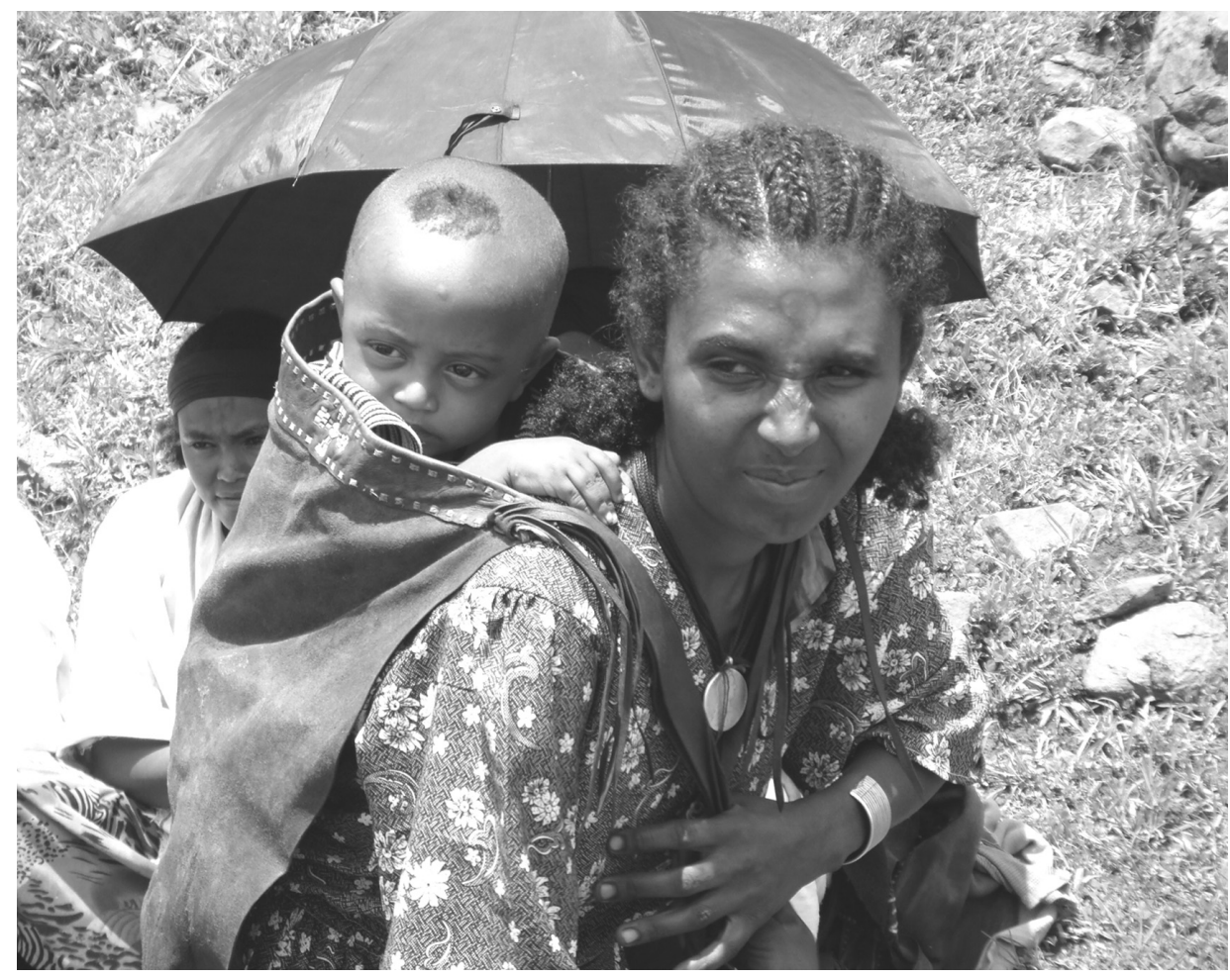

In addition to unmarried girls, Berhane Hewan serves married girls, providing informal education and conducting peer group meetings to reduce social isolation.
14 in Mosebo had married during the previous year. However, marriage was more common for older girls in Mosebo, after the age of 15, than it was in Enamirt, as some girls in Mosebo who had avoided marriage at a younger age got married in their late teens.

"This was perhaps due to the social expectation for marriage during adolescence and its linkage with the status of the girl's father. In Ethiopia, girls who are not married by late adolescence are considered a disgrace to
Percent of adolescent girls married at endline, by age and area of residence

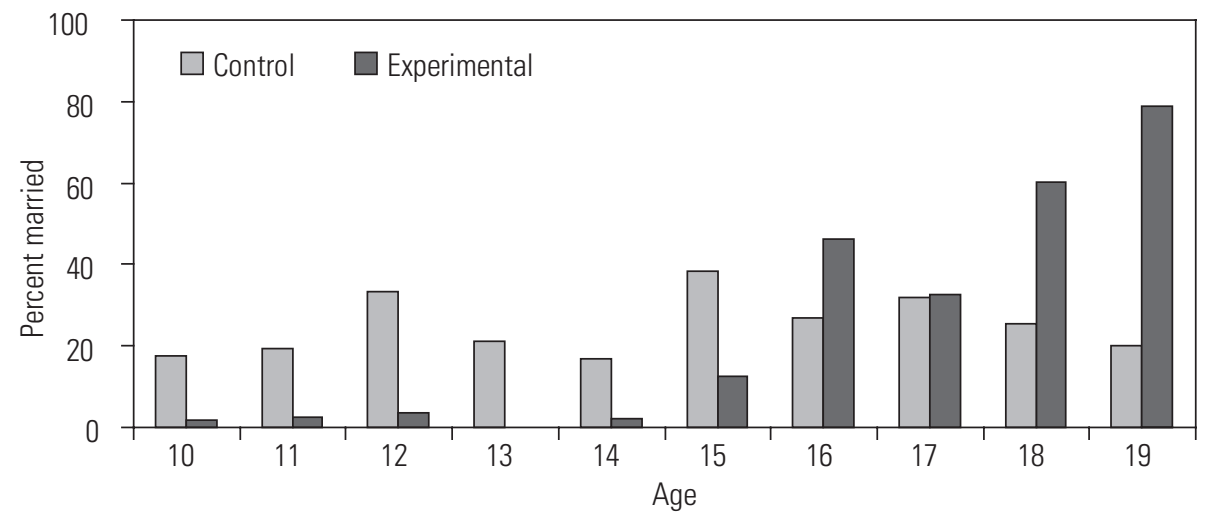

their family," explained Erulkar. "Nevertheless, girls in Mosebo were given a few critical extra years in which to expand their social networks, attend school, learn more skills, and develop as individuals."

Because most girls participated in all program components, it is difficult to tell whether specific components were more influential than others in bringing about change. The Berbane Hewan experiment demonstrates that significant impacts can be made on the social, educational, and health status of adolescent girls in a short period of time, through well-designed and -implemented support programs for girls. Based on this success, the program has been expanded and now enrolls 12,000 girls in rural Ethiopia, including in Enamirt.
SOURCE

Erulkar, Annabel S. and Eunice Muthengi. 2009. "Evaluation of Berhane Hewan: A program to delay child marriage in rural Ethiopia," International Perspectives on Sexual and Reproductive Health 35(1): 6-14.

\section{OUTSIDE FUNDING}

The Nike Foundation, UK Department for International Development, United Nations Population Fund, United Nations Foundation 


\section{Family Planning Programs Remarkably Successful}

Do large-scale family planning programs improve the well-being of people, economies, and the environment? In recent years, critics have argued that the need for such programs has receded and that they are less crucial than other programs that compete for development aid. Partially as a result of these claims, funding for international family planning programs in developing countries has declined by 30 percent since the mid-1990s.

Population Council vice president and distinguished scholar John Bongaarts and Guttmacher Institute senior fellow Steven W. Sinding aimed to set the record straight in a recent article in the journal International Perspectives on Sexual and Reproductive Health. They urge that investment in family planning become a higher priority on the international development agenda. They show that decisions by policymakers and donors to reduce investments in contraceptive research, services, and supplies were in part based on plausible-sounding, but mistaken, arguments. In reality, family planning programs are a cost-effective way to address many of the needs of the world's most vulnerable people.

\section{Family planning programs bave a significant effect on fertility}

Decades of research show that comprehensive family planning and reproductive health services lead to sharp rises in contraceptive use that help women avoid unintended pregnancies. Over a 30-year period (1960-90), fertility declined in the developing world from more than six to fewer than four births per woman, and almost half of that decline- 43 percent-is attributable to family planning programs.

Despite these drops in fertility, the United Nations still forecasts that the earth's population will grow by 2.7 billion between 2005 and 2050 . Nearly all of this growth will happen in the developing world, which has the fewest resources to deal with the strains on economies and the environment caused by population growth.
Reasons for this continued growth include the following:

- Current birth rates leave fertility substantially above the level needed to bring about population stabilization.

- People live longer as higher standards of living, better nutrition, expanded health services, and greater investments in public health have reduced death rates. Further improvements are likely.

- The large number of young people entering their childbearing years will result in population growth for decades to come, a phenomenon known as population momentum. In sub-Saharan Africa, 43 percent of the total female population was younger than 15 years in 2005 .

\section{Even with the HIV epidemic, family planning is necessary}

Despite the substantial mortality from AIDS, UN projections for all developing regions predict further large population increases. In sub-Saharan Africa, where the toll of the epidemic is largest, the region's population is expected to grow by one billion between 2005 and 2050. The annual number of AIDS deaths worldwide (2 million) is equivalent to just 10 days' growth in the population of the developing world.

Large-scale family planning programs appear to improve public health on the same scale as other health interventions such as basic sanitation for diarrheal disease, a short course of treatment for tuberculosis, and condom distribution for HIV prevention. All of these interventions are much more cost-effective than antiretroviral treatment of AIDS, which currently receives a large proportion of healthrelated development aid.

\section{Family planning programs empower women}

Today, nearly all family planning programs around the world respect the right of couples to make informed reproductive choices, free from undue persuasion or coercion. Bongaarts and Sinding acknowledge that an important exception is China, where the one-child policy continues to violate reproductive rights standards.

However, "in our view," they write, "the absence of access to contraception should also be considered a form of coercion, because it frequently condemns women to bearing children they do not wish to have."

Population growth and what to do about it has been the subject of controversy since the 1700s. Perhaps because at its most fundamental level the subject deals with sex, it has been a heated topic of public policy debate. Yet, argue Bongaarts and Sinding, much of today's discussion about family planning programs, the main way in which population policies have been implemented over the past 50 years, is based on faulty perceptions and misinformation. Large-scale national family planning programs have, for the most part, been remarkably successful.

Why does this debate matter? Because women and children continue to suffer and die as a consequence of unintended childbearing. Crucially, unsustainable population growth has been linked with environmental degradation, governmental instability, food scarcity, and pervasive poverty.

"In the face of declining political and financial commitment to family planning programs, we must address head-on the faulty criticisms that have held back efforts to satisfy the unmet demand for family planning services," say Bongaarts and Sinding. "High fertility and rapid population growth remain real problems that merit our attention and action." -

\section{SOURCE}

Bongaarts, John and Steven W. Sinding. 2009. "A response to critics of family planning programs," International Perspectives on Sexual and Reproductive Health 35(1): 39-44.

\section{OUTSIDE FUNDING}

The William and Flora Hewlett Foundation 


\section{HIV AND AIDS}

Baek, Carolyn, Tracy Creek, Lee Ann Jones, Louis Apicella, Jennifer Redner, and Naomi Rutenberg. “Evaluation of HIV counseling and testing in ANC settings and adherence to short course antiretrovira prophylaxis for PMTCT in Francistown, Botswana," Horizons Final Report. Washington, DC: Population Council.

Bhuiya, Ismat and Ubaidur Rob (eds.). 2008. “Jibon Dokkhota Shikkhar Maddame Jouno Siddhanto Shaktishalikoron-A peer educator Proshikkhon manual" [Strengthening safe sex decision-making through life skills based peer education]. Dhaka: National AIDS/STD Program and Save the ChildrenUSA

Birungi, Harriet, John F. Mugisha, Francis Obare, and Juliana K. Nyombi. "Sexual behavior and desires among adolescents perinatally infected with human immunodeficiency virus in Uganda: Implications for programming," Journal of Adolescent Health 44(2): 184-187.

Harrison, Polly, John W. Mellors, Barbara Richardson, Benoit R. Masse, Qurraisha Karim, Salim S. Abdool Karim, Ward Cates, Anne S. Coletti, Janet Darbyshire, Laneta J. Dorflinger, Paul Feldblum, Henry Gabelnick, Vera Grigorieva Halpern, Sharon L. Hillier, Vicky Jespers, Ayesha B.M. Kharsany, Sheena McCormack, Andrew Nunn, Ian McGowan, Rabeea F. Omar, Nancy F. Padian, Louise Pedneault, Melissa Pope Robbiani, James Sailer, Douglas Taylor, Elizabeth E. Tolley, Lut Van Damme, Sten H. Vermund, and Janneke van de Wijgert. 2008. "Challenges in HIV-prevention microbicide research [e-letter response to Grant et al., 2008: "Whither or wither microbicides"]," Science, 17 December 2008.

Hossain, Sharif Mohammed Ismail, Ubaidur Rob, Khandoker Abu Jafar Saleh, Mohammad Alam, M.R. Khan, Mohammad Shahid Hossain, Yasmin H. Ahmed Avik Rahman, Tanzina Ahmed, and Rakesh Cakrabarty. 2008. "Mapping of garment factories in Dhaka division, Bangladesh." Dhaka: Population Council.

Hossain, Sharif Mohammed Ismail, Ubaidur Rob, Khandoker Abu Jafar Saleh, Mohammad Alam, M.R. Khan, Mohammad Shahid Hossain, Yasmin H. Ahmed, Avik Rahman, Tanzina Ahmed, and Rakesh Cakrabarty. 2008. "Needs assessment of garment workers in relation to $\mathrm{RH}, \mathrm{STI}$ and HIV/AIDS in Dhaka division, Bangladesh." Dhaka: Population Council.

"MSM consultation stimulates action to address 'the overlooked epidemic,'" fact sheet. Nairobi: Population Council, 2008.

National AIDS/STD Programme, Save the ChildrenUSA, Bangladesh International Center for Diarrhoeal Disease Research, and Population Council. "Creating conditions for scaling up access to life skills based sexual and reproductive health education and condom services: Strengthening safe sex decision-making." Dhaka: National AIDS/STD Program and Save the Children-USA.

Rahman, A., Shimol Koli Hossain, and Ismat Bhuiya (eds.). 2008. "HIV/AIDS Bishoyok master trainer module" [Master trainer module on HIV/AIDS issues]. Dhaka: National AIDS/STD Program and Save the Children-USA.

Reddy, P., S. James, H. Mutumba Bilay-Boon, E. Williams, and Hena Khan. "Pilot community-based intervention to address the needs of elderly caregivers in the Eastern Cape Province, South Africa," Horizons
Research Summary. Washington, DC: Population Council.

Saggurti, Niranjan, Vaishali Sharma Mahendra, Rajendra Singh, Saumya RamaRao, Suvakanta N. Swain, Ajay Kumar Singh, Anrudh K. Jain, and Ravi K. Verma. 2008. "Patterns of migration/mobility and HIV risk among female sex workers: Maharashtra 2007-08." New Delhi: Population Council.

Saggurti, Niranjan, Ravi K. Verma, Anrudh K. Jain, Saumya RamaRao, Anil K. Kumar, Anjaneyulu Subbiah, Hamini Reddy Modugu, Shiva Halli, and Shalini Bharat. 2008. "HIV risk behaviours among contracted and noncontracted male migrant workers in India: Potential role of labor contractors and contractual systems in HIV prevention," AIDS 22(Suppl 5): S127-S136.

\section{Sheehy, Meredith, Mini Nomtandazo, Tonica} Mophanga, and Scott Kellerman. "Family centred approach for HIV services: Pilot study in South Africa," Horizons Research Summary. Washington, DC: Population Council.

Skoler-Karpoff, Stephanie, Barbara Friedland, Marlena Gehret Plagianos, Robin A. Maguire, and Pekka Lähteenmaki. "Vaginal microbicide adherence biomarkers should be validated-Authors' reply," Lancet 373(9665): 721-722.

Skoler-Karpoff, Stephanie, Gita Ramjee, Khatija Ahmed, Lydia Altini, Marlena Gehret Plagianos, Barbara A. Friedland, Sumen Govender, Alana de Kock, Nazira Cassim, Thesla Palanee, Gregory Dozier, Robin A. Maguire, and Pekka Lähteenmäki. 2008. "Efficacy of Carraguard for prevention of HIV infection in women in South Africa: a randomised, double-blind, placebocontrolled trial," Lancet372(9654): 1977-1987.

Solomon, Suniti, Kartik K. Venkatesh, Lisanne Brown, P. Verma, Anitha J. Cecelia, C. Daly, Vaishali Sharma Mahendra, N. Cheng, N. Kumarasamy, and Kenneth H. Mayer. 2008. “Gender-related differences in quality of life domains of persons living with HIV/AIDS in South India," AIDS Patient Care and STDs 22(12): 999-1005.

Subbiah, Anjaneyalu, S. Ramachandran, A.K. Ravi Shankar, Niranjan Saggurti, Ravi K. Verma, Anrudh K. Jain, Saumya RamaRao, Suvakanta N. Swain, and Ajay Kumar Singh. 2008. "Migration/mobility and vulnerability to HIV among male migrant workers: Tamil Nadu 200708." New Delhi: Population Council.

Thorpe, Lorna E., Ushma D. Upadhyay, Shadi Chamany, Renu Garg, Jenna Mandel-Ricci, Scott Kellerman, Diana K. Berger, Thomas R. Frieden, and Charon Gynn. "Prevalence and control of diabetes and impaired fasting glucose in New York City," Diabetes Care 32(1): $57-62$.

Trapp, Susanna, Nina R. Derby, Rachel Singer, Andrew Shaw, Vennansha G. Williams, Stuart G. Turville, Julian W. Bess Jr., Jeffrey D. Lifson, and Melissa Robbiani. “Double-stranded RNA analog poly(l:C) inhibits human immunodeficiency virus amplification in dendritic cells via type I interferon-mediated activation of APOBEC3G, Journal of Virology 83(2): 884-895.

"Trial statistics for the Phase 3 efficacy and long-term safety trial of the candidate microbicide Carraguard," fact sheet. New York: Population Council, 2008.

\section{POVERTY, GENDER, AND YOUTH}

Acharya, Rajib, Shveta Kalyanwala, Shireen J. Jejeebhoy, and Vinita Nathani. "Broadening girls" horizons: Effects of life skills education programme in rural Uttar Pradesh." New Delhi: Population Council.
Awusabo-Asare, Kofi and Population Council. “Demographic Data for Development: Ghana." New York: Population Council.

Baldwin, Wendy. “Demographic Data for Development: Overview report." New York: Population Council.

Barker, Gary, Deniz Dogruöz, and Debbie Rogow. "And how will you remember me, my child? Redefining fatherhood in Turkey," Quality/Calidad/Qualité no. 19. New York: Population Council.

Biddlecom, Ann E., Richard Gregory, Cynthia B. Lloyd, and Barbara S. Mensch. 2008. “Associations between premarital sex and leaving school in four sub-Saharan African countries," Studies in Family Planning 39(4): 337-350.

Bongaarts, John. 2008. "What can fertility indicators tell us about pronatalist policy options?" Vienna Yearbook of Population Research 2008: 39-55.

Bongaarts, John and Steven W. Sinding. "A response to critics of family planning programs," International Perspectives on Sexual and Reproductive Health 35(1): 39-44.

Bongaarts, John, Richard G. Wamai, Helen A. Weiss, Catherine Hankins, Kawango Agot, et.al. 2008. “Male circumcision is an efficacious, lasting and costeffective strategy for combating HIV high-prevalence AIDS epidemics: Time to move beyond debating the science," Future HIV Therapy 2(5): 399-405 [letter to the editor].

Bruce, Judith. 2008. “La siguiente generación de programas para adolescentes: satisfacer las necesidades interrelacionadas de salud, sociales y económicas del sector poblacional más vulnerable," in C. Stern (ed.), Adolescentes en México. Investigación, experiencias y estrategias para mejorar su salud sexual y reproductiva. México, DF: El Colegio de México y Population Council.

"Child marriage in francophone West Africa," fact sheet. New York: Population Council, 2008.

"Day of Dialogue: Sharing insights and evidence on the female condom in Ghana," report from a 24 November 2008 consultation in Accra, Ghana. New York: Population Council.

Erulkar, Annabel S. and Awraris Alemayehu. "Addis Birhan ('New Light'): Fostering husbands' involvement and support in Amhara Region, Ethiopia," program brief. Addis Ababa: Population Council.

Erulkar, Annabel S. and Eunice Muthengi. “Evaluation of Berhane Hewan: A program to delay child marriage in rural Ethiopia," International Perspectives on Sexual and Reproductive Health 35(1): 6-14.

"Factsheet: Youth in India: Situation and needs-Key indicators, 2006-2007: Andhra Pradesh." New Delhi: Population Council, 2008.

"Factsheet: Youth in India: Situation and needs-Key indicators, 2006-2007: Rajasthan." New Delhi: Population Council, 2008

Grant, Monica J. and Kelly Hallman. 2008. “Pregnancyrelated school dropout and prior school performance in KwaZulu-Natal, South Africa," Studies in Family Planning 39(4): 369-382.

Hallman, Kelly. 2008. "Researching the determinants of vulnerability to HIV among adolescents," IDS Bulletin 39(5): 36-44. 
International Institute for Population Sciences (IIPS) and Population Council. 2008. "Education and transition to work among youth in Maharashtra," Youth in India: Situation and Needs Policy Brief no. 3. Mumbai: IIPS.

International Institute for Population Sciences (IIPS) and Population Council. 2008. "How early marriage compromises girls' lives, Maharashtra," Youth in India: Situation and Needs Policy Briefno. 6. Mumbai: IIPS.

International Institute for Population Sciences (IIPS) and Population Council. 2008. "Parents matter: How supportive parenting influences the behaviours of youth, Maharashtra," Youth in India: Situation and Needs Policy Brief no. 4. Mumbai: IIPS.

International Institute for Population Sciences (IIPS) and Population Council. 2008. "Romance and sex before marriage among young women and men in Maharashtra," Youth in India: Situation and Needs Policy Brief no. 5. Mumbai: IIPS.

International Institute for Population Sciences (IIPS) and Population Council. 2008. "Sexuality education for youth in Maharashtra: Yes or no?" Youth in India: Situation and Needs Policy Brief no. 2. Mumbai: IIPS

International Institute for Population Sciences (IIPS) and Population Council. 2008. "Young people's participation in civil society and political life in Maharashtra," Youth in India: Situation and Needs Policy Brief no. 1. Mumbai: IIPS.

International Institute for Population Sciences (IIPS) and Population Council. "Youth in India: Situation and needs 2006-2007, executive summary, Maharashtra." Mumbai: IIPS.

International Institute for Population Sciences (IIPS) and Population Council. 2008. "Youth in India: Situation and needs 2006-2007 Maharashtra," report. Mumbai: IIPS.

Juárez, Fatima, Thomas LeGrand, Cynthia B. Lloyd, and Susheela Singh. 2008. "Introduction to special issue on adolescent sexual and reproductive health in sub-Saharan Africa," Studies in Family Planning 39(4): 239-244.

Kibombo, Richard and Population Council. “Demographic Data for Development: Uganda." New York: Population Council.

Lloyd, Cynthia B. and Barbara S. Mensch. 2008.

"Pregnancy and marriage are not the main reasons for leaving school in Africa," International Family Planning Perspectives 34(3): 147-148.

Lloyd, Cynthia B., Cem Mete, and Monica J. Grant. "The implications of changing educational and family circumstances for children's grade progression in rural Pakistan: 1997-2004," Economics of Education Review 28(1): 152-160.

Maruru, Rose and Population Council. "Demographic Data for Development: Senegal." New York: Population Council.

Mekonnen, Yared and Population Council. "Demographic Data for Development: Ethiopia." New York: Population Council.

Mensch, Barbara S., Paul C. Hewett, Richard Gregory, and Stephane Helleringer. 2008. "Sexual behavior and STI/HIV status among adolescents in rural Malawi: An evaluation of the effect of interview mode on reporting," Studies in Family Planning 39(4): 321-334.

Mensch, Barbara S., Paul C. Hewett, Heidi E. Jones, Carla Gianni Luppi, Sheri A. Lippman, Adriana A. Pinho, and Juan Díaz. 2008. “Consistency in women's reports of sensitive behavior in an interview mode experiment, São Paulo, Brazil," International Family Planning Perspectives 34(4): 169-176.
Montgomery, Mark R. “Review of World Bank, World Development Report 2009: Reshaping Economic Geography," Population and Development Review35(1): 197-199.

Naik, Reshma and Martha Brady. 2008. “The female condom in Ghana: Exploring the current state of affairs and gauging potential for enhanced promotion." Accra: Population Council.

Population Council and Liverpool VCT, Care \& Treatment. “Female-initated prevention: Integrating female condoms into HIV risk-reduction activities in Kenya." Nairobi: Population Council.

“Poverty, Gender, and Youth Program: From demography to policy," fact sheet. New York: Population Council.

Santhya, K.G. “Understanding pregnancy-related morbidity and mortality among young women in Rajasthan." New Delhi: Population Council.

“Understanding adolescent girls' protection strategies gainst HIV: Exploratory research in Zambia," Poverty, Gender, and Youth Project Brief. New York: Population Council, 2008.

\section{REPRODUCTIVE HEALTH}

Abdel-Tawab, Nahla, Sarah Loza, and Amal Zaki. 2008. “Helping Egyptian women achieve optimal birth spacing intervals through fostering linkages between family planning and maternal/child health services," FRONTIERS Final Report. Washington, DC: Population Council.

Bak, Beata, Laura Carpio, Jinjing L. Kipp, Pankaj Lamba Ying Wang, Renshan Ge, Matthew P. Hardy*, Kelly E. Mayo, and Daniel J. Bernard. "Activins regulate 17 $\beta$ hydroxysteroid dehydrogenase type I transcription in murine gonadotrope cells," Journal of Endocrinology 201(1): 89-104.

Bendikson, Kristin A., Queenie V. Neri, Takumi Takeuchi, Marco Toschi, Peter N. Schlegel, Zev R. Rosenwaks, and Gianpiero D. Palermo. 2008. "The outcome of intracytoplasmic sperm injection using occasional spermatozoa in the ejaculate of men with spermatogenic failure," Journal of Urology 180(3): 1060-1064.

Brache, Vivian, Horacio Croxatto, Narender Kumar, Régine Sitruk-Ware, Leila Cochon, Veronica Schiappacasse, Irving Sivin, Carla Muñoz, Robin A. Maguire, and Anibal Faundes. "Effect of sexual intercourse on the absorption of levonorgestrel after vaginal administration of $0.75 \mathrm{mg}$ in Carraguard $^{\circledR}$ gel: $^{\prime}$ A randomized, cross-over, pharmacokinetic study," Contraception 79(2): 150-154.

Chen, Bing-Bing, Han Lin, Guo-Xin Hu, Ying Su, Hong-Yu Zhou, Oing-Quan Lian, Hui Cai, Dianne 0. Hardy, DingYing Gu, and Renshan Ge. "The (+)- and (-)-gossypols potently inhibit human and rat 11ß-hydroxysteroid dehydrogenase type 2," Journal of Steroid Biochemistry and Molecular Biology 113(3-5): 177-181.

Collins, John, Kurt T. Barnhart, and Peter N. Schlegel. 2008. "Do sperm DNA integrity tests predict pregnancy with in vitro fertilization?" Fertility and Sterility 89(4): 823-831.

“Current Population Council projects on emergency contraception," fact sheet. New York: Population Council, 2008.

Diagne, Anta Fall. 2008. "Lutte contre la pratique de I'excision au Mali: De l'approche santé à l'approche basée sur les droits de l'enfant-Rapport d'Evaluation du Programme du Centre Djoliba." Dakar: Save the Children/Sweden and Population Council. (Executive summary in English; report in French)
Eifler Jr., John B., Peggy King, and Peter N. Schlegel. 2008. "Incidental testicular lesions found during infertility evaluation are usually benign and may be managed conservatively," Journal of Urology 180(1): 261-265.

“Emergency contraception: Health care providers quick reference guide." Nairobi: Kenya Ministry of Public Health \& Sanitation, Division of Reproductive Health, 2008.

Fan, Liqiang, Dianne 0. Hardy, James F. Catterall, Jian Zhao, and Suxia Li. 2008. "Identification and characterization of the minimal androgen-regulated kidney-specific kidney androgen-regulated protein gene promoter," Acta Biochimica et Biophysica Sinica 40(12): 979-988.

Fu, Xiao-Dong, Maria Silva Giretti, Lorenzo Goglia, Marina Ines Flamini, Angel Matias Sanchez, Chiara Baldacci, Silvia Garibaldi, Régine Sitruk-Ware, Andrea Riccardo Genazzani, and Tommaso Simoncini. 2008. “Comparative actions of progesterone, medroxyprogesterone acetate, drospirenone and nestorone on breast cancer cell migration and invasion," BMC Cancer 8: 166.

Grossman, Daniel, Leticia Fernandez, Kristine Hopkins, Jon Amastae, Sandra G. García, and Joseph E. Potter. 2008. "Accuracy of self-screening for contraindications to combined oral contraceptive use," Obstetrics and Gynecology 112(3): 572-578.

"Health facts about emergency contraceptive pills," fact sheet. New York: Population Council, 2008.

Hu, Guo-Xin, Lu-Feng Hu, Dai-Zheng Yang, Jun-Wei Li, Guo-Rong Chen, Bing-Bing Chen, Dolores D. Mruk, Michele Bonanomi, Bruno Silvestrini, Chuen-yan Cheng, and Renshan Ge. "Adjudin targeting rabbit germ cell adhesion as a male contraceptive: A pharmacokinetics study," Journal of Andrology 30(1): 87-93.

Hu, Guo-Xin, Qing-Quan Lian, Han Lin, Syed A. Latif, David J. Morris, Matthew P. Hardy*, and Renshan Ge. 2008. "Rapid mechanisms of glucocorticoid signaling in the Leydig cell," Steroids 73(9-10): 1018-1024.

Hu, Guo-Xin, Han Lin, Chantal M. Sottas, David J. Morris, Matthew P. Hardy*, and Renshan Ge. 2008. "Inhibition of 11ß-hydroxysteroid dehydrogenase enzymatic activities by glycyrrhetinic acid in vivo supports direct glucocorticoid-mediated suppression of steroidogenesis in Leydig cells," Journal of Andrology 29(3): $345-351$

Hunnicutt, Gary R., Dennis E. Koppel, Susanna Kwitny, and Ann E. Cowan. 2008. "Cyclic 3',5'-AMP causes ADAM1/ADAM2 to rapidly diffuse within the plasma membrane of guinea pig sperm," Biology of Reproduction 79(5): 999-1007.

Juárez, Fatima, Susheela Singh, Sandra G. García, and Claudia Díaz-Olavarrieta. 2008. “Estimates of induced abortion in Mexico: What's changed between 1990 and 2006?" International Family Planning Perspectives 34(4): 158-168.

Keesbury, Jill, Ian Askew, John Townsend, Ricardo Vernon, M.E. Khan, and Sharif Mohammed Ismail Hossain. "ECP handbook: Introducing and mainstreaming the provision of emergency contraceptive pills in developing countries." Washington, DC: Population Council.

"Kenya and Ethiopia: Community and religious leaders are effective advocates for HIV testing for young couples," FRONTIERS OR Summary no. 80. Washington, DC: Population Council, 2008

Khan, M.E., Aruna Bhattacharya, Ismat Bhuiya, and Aditi Aeron. 2008. "A situation analysis of care and support for rape survivors at first point of contact 
in India and Bangladesh," FRONTIERS Final Report. Washington, DC: Population Council.

Khan, M.E., Sohini Roychowdhury, Mary Philip Sebastian, Sitanshu Sekhar Kar, Anurag Mishra, Vivek Sharma, G. Narayana, Bhawana Sharma, Nahla AbdelTawab, and Ahmed Afifi. 2008. "Technical assistance for implementing best practices in the Asia and Near East region," FRONTIERS Final Report. Washington, DC: Population Council.

Kim, Howard H. and Marc Goldstein. 2008. "Adult varicocele," Current Opinion in Urology 18(6): 608-612.

Kim, Howard H. and Marc Goldstein. "High

complication rates challenge the implementation of male circumcision for HIV prevention in Africa," Nature Clinical Practice Urology 6(2): 64-65.

Kim, Howard H. and Peter N. Schlegel. 2008. "Endocrine manipulation in male infertility," Urologic Clinics of North America 35(2): 303-318.

Lee, J.G., Renshan Ge, Dianne 0. Hardy, K. Leong, D.M. Nanus, Matthew P. Hardy*, and R. Shen. 2008 "Modulation of 11 $\beta$-hydroxysteroid dehydrogenase expression by bombesin: A possible mechanism for glucocorticoid resistance in androgen independent prostate cancer," Hormone and Metabolic Research 40(11): 772-778.

Lee, Nikki P.Y., Elissa W.P. Wong, Dolores D. Mruk, and Chuen-yan Cheng. "Testicular cell junction: A novel target for male contraception," Current Medicinal Chemistry 16(7): 906-915.

Lee, Richard, Marc Goldstein, Brant W. Ullery, Joshua Ehrlich, Marc Soares, Renee A. Razzano, Michael Herman, Mark A. Callahan, Philip S. Li, Peter N. Schlegel, and Steve S. Witkin. "Value of serum antisperm antibodies in diagnosing obstructive azoospermia," Journal of Urology 181(1): 264-269.

Lee, Richard, Philip S. Li, Peter N. Schlegel, and Marc Goldstein. 2008. “Reassessing reconstruction in the management of obstructive azoospermia: Reconstruction or sperm acquisition?" Urologic Clinics of North America 35(2): 289-301.

Liu, Peter Y., Ronald S. Swerdloff, Bradley D. Anawalt, Richard A. Anderson, William J. Bremner, Joerg Elliesen, Yi-Qun Gu, Wendy M. Kersemaekers, Robert I. McLachlan, M. Christina Meriggiola, Eberhard Nieschlag, Régine Sitruk-Ware, Kirsten M. Vogelsong, Xing-Hai Wang, Frederick C.W. Wu, Michael Zitzmann, David J. Handelsman, and Christina Wang. 2008.

"Determinants of the rate and extent of spermatogenic suppression during hormonal male contraception: An integrated analysis," Journal of Clinical Endocrinology and Metabolism 93(5): 1774-1783.

Mir, Ali Mohammad, Laura Reichenbach, Abdul Wajid, and Mumraiz Khan. 2008. “Study of sexually transmitte infections among urban men in Pakistan: Identifying the bridging population," report. Islamabad: Population Council.

Mruk, Dolores D. and Ann S.N. Lau. “RAB13 participates in ectoplasmic specialization dynamics in the rat testis," Biology of Reproduction 80(3): 590-601.

Mruk, Dolores D., Bruno Silvestrini, and Chuen-yan Cheng. 2008. "Anchoring junctions as drug targets: Role in contraceptive development," Pharmacological Reviews 60(2): 146-180.
Mullick, Saiqa, Mantshi Menziwa, Nzwakie Mosery Doctor Khoza, and Edwin Maroga. 2008. "Feasibility, acceptability, effectiveness and cost of models of integrating HIV prevention and counseling and testing for HIV within family planning services in North West Province, South Africa," FRONTIERS Final Report Washington, DC: Population Council.

Osei, Ivy, Gertrude Voetagbe, Moses Aikins, John Gyapong, Philomena Nyarko, Harriet Birungi, Gloria 0. Asare, Henrietta Odoi-Agyarko, and Olivia Aglah. 2008.

“Comparing the effectiveness and costs of alternative strategies for improving access to information and services for the IUD in Ghana," FRONTIERS Final

Report. Washington, DC: Population Council.

"Periodic presumptive treatment for sexually transmitted infections: Experience from the field and recommendations for research." Geneva: World Health Organization, 2008.

Population Council and Liverpool VCT Care \& Treatment. "Female-initated prevention: Integrating female condoms into HIV risk-reduction activities in Kenya." Nairobi: Population Council.

"Population Council research and technical assistance on emergency contraception," fact sheet. New York: Population Council, 2008

Raney, Laura, Mantshi Menziwa, Wilson Liambila, Ian Askew, Doctor Khoza, Linda Bruce, and Saiqa Mullick. 2008. Balanced Counseling Strategy Plus: A Toolkit for Family Planning Service Providers Working in High HIV/STI Prevalence Settings. Washington, DC: Population Council.

Rivero-Fuentes, Estela, Saumya RamaRao, Ricardo Estrada, Charlotte Warren, Saiqa Mullick, Ian Askew, Harriet Birungi, John Townsend, and Susana Medina. 2008. "Assessing Integration Methodology (AIM): A handbook for measuring and assessing the integration of family planning and other reproductive health services." Washington, DC: Population Council.

Sarkar, Oli, Premendu P. Mathur, Chuen-yan Cheng, and Dolores D. Mruk. 2008. "Interleukin 1 Alpha (IL1A) is a novel regulator of the blood-testis barrier in the rat," Biology of Reproduction 78(3): 445-454.

Schlegel, Peter N. "Nonobstructive azoospermia: A revolutionary surgical approach and results," Seminars in Reproductive Medicine 27(2): 165-170.

Schumacher, Michael, Régine Sitruk-Ware, and Alejandro De Nicola. 2008. "Progesterone and progestins: Neuroprotection and myelin repair," Current Opinion in Pharmacology 8(6): 740-746.

"Scientific Writing for Reproductive Health Programs/ Redacción Científica para Programas de Salud Reproductiva." Washington, DC: Population Council, 2008.

Sitruk-Ware, Régine. 2008. “Does estrogen therapy reduce coronary artery calcification in postmenopausal women?" Nature Clinical Practice Endocrinology and Metabolism 4(1): 12-13.

Tanrikut, Cigdem and Marc Goldstein. "Obstructive azoospermia: A microsurgical success story," Seminars in Reproductive Medicine 27(2): 159-164.

Vishwanath Prasad, Pramod, Ramamani Arumugam, Mark Willman, Renshan Ge, Régine Sitruk-Ware, and Narender Kumar. "Distribution, metabolism and excretion of a synthetic androgen $7 \alpha$-methyl-19nortestosterone, a potential male-contraceptive," Steroids 74(1): 121-131.

Warren, Charlotte and Annie Mwangi. 2008. "Obstetric fistula: Can community midwives make a difference? Findings from four districts in Kenya." Nairobi: Population Council.

Warren, Charlotte, Semakaleng Phafoli, Bosielo Majara, and Thato Tsukuluet. 2008. “Extending prevention of mother-to-child transmission through postpartum family planning in Lesotho," FRONTIERS Final Report. Washington, DC: Population Council.

Wilson, Katherine, Sandra G. García, and Diana Lara. 2008. "Methods for estimating abortion incidence and abortion-related morbidity: A review," a publication of papers presented at the IUSSP Seminar on the Measurement of Abortion Incidence, Abortion-Related Morbidity and Mortality, 7-9 November 2007, Paris, France.

Wong, Elissa W.P., Dolores D. Mruk, and Chuen-yan Cheng. 2008. "Biology and regulation of ectoplasmic specialization, an atypical adherens junction type, in the testis," Biochimica et Biophysica Acta 1778(3): 692-708.

Wong, Elissa W.P., Dolores D. Mruk, Will M. Lee, and Chuen-yan Cheng. 2008. "Par3/Par6 polarity complex coordinates apical ectoplasmic specialization and blood-testis barrier restructuring during spermatogenesis," Proceedings of the Nationa Academy of Sciences of the United States of America 105(28): 9657-9662.

Xia, Weiliang, Elissa W.P. Wong, Dolores D. Mruk, and Chuen-yan Cheng. "TGF- $\beta 3$ and TNF $\alpha$ perturb blood-testis barrier (BTB) dynamics by accelerating the clathrin-mediated endocytosis of integral membrane proteins: A new concept of BTB regulation during spermatogenesis," Developmental Biology 327(1): 48-61.

Yan, Helen H.N., Dolores D. Mruk, Will M. Lee, and Chuen-yan Cheng. 2008. "Blood-testis barrier dynamics are regulated by testosterone and cytokines via their differential effects on the kinetics of protein endocytosis and recycling in Sertoli cells," FASEB Journal 22(6): 1945-1959.

Yan, Helen H.N., Dolores D. Mruk, Elissa W.P. Wong, Will M. Lee, and Chuen-yan Cheng. 2008. "An autocrine axis in the testis that coordinates spermiation and blood-testis barrier restructuring during spermatogenesis," Proceedings of the National Academy of Sciences of the United States of America 105(26): 8950-8955.

Zhang, Junhui, Renshan Ge, Catherine Matte-Martone, Julie Goodwin, Warren D. Shlomchik, Mark J. Mamula, Ali Kooshkabadi, Matthew P. Hardy*, and David Geller. "Characterization of a novel gain of function glucocorticoid receptor knock-in mouse," Journal of Biological Chemistry 284(10): 6249-6259.

\section{OTHER PUBLICATIONS}

Population and Development Review 35(1) and 35(2)

Studies in Family Planning 40(1) and 40(2) 


\section{Trial Showed Anti-HIV Microbicide Candidate Is Safe, but Did Not Prove It Effective}

\begin{abstract}
A Phase 3 clinical trial in South Africa of the Population Council's candidate microbicide, Carraguard $^{\circledR}$, showed the gel to be safe for vaginal use when applied approximately once per week, on average, for up to two years. The trial did not demonstrate that Carraguard is effective in preventing male-to-female transmission of HIV during sex. In February 2008, when the results were finalized, the Population Council announced these results and informed South African trial participants, government officials, advocates, and other scientists. In December 2008, the results were published in The Lancet. The Carraguard Phase 3 trial, a milestone in microbicide development, was the first such trial of a candidate microbicide to be completed with no safety concerns.
\end{abstract}

\section{Clinical trial in South Africa}

The Carraguard trial, which began in March 2004 and ended in March 2007, enrolled 6,202 women and was conducted at three sites in South Africa: the Setshaba Research Centre, through the University of Limpopo/Medunsa campus; the Empilisweni Centre for Wellness Studies, through the University of Cape Town; and the Isipingo Clinic, through the Medical Research Council of South Africa. These sites are located in areas where the HIV epidemic is acute.

Half of the women enrolled in the Phase 3 study were given Carraguard gel and condoms, and the other half received a placebo gel and condoms. There were 134 new HIV infections in the Carraguard group (an incidence of 3.3 infections per 100 woman-years) and 151 new infections in the placebo group (an incidence of
3.8 infections per 100 woman-years). The difference in infection rates between the two groups is not statistically significant, thus the product was not found to be effective.

\section{Carrageenan}

Carraguard is made from carrageenan, a seaweed derivative that is on the US Food and Drug Administration's list of products "Generally Recognized As Safe" for consumption and topical application. Carrageenan has been used for decades as a thickening agent in many products, including infant formula, soups, and ice cream.

Laboratory research has shown Carraguard to be effective in blocking cells from becoming infected by HIV and human papillomavirus and in protecting mice from herpes simplex infection. Carraguard and similar carrageenan formulations had undergone extensive safety testing involving more than 850 women and men in earlier clinical trials in Australia, Chile, the Dominican Republic, Finland, South Africa, Thailand, and the United States.

Obtaining truly informed consent from individuals participating in human clinical trials has been a cornerstone of the Population Council's microbicide research. Thus, the Council's public health and social scientists collaborated closely with women's health advocates and local community members to ensure that the ethical and practical challenges of testing and introducing microbicides were addressed. Further, the Population Council and our research partners aimed to provide the highest standard of care to women enrolled in the clinical trial as well as to women who volunteered but did not participate in the trial. Services included testing and treatment for sexually transmitted infections, pre- and post-test counseling for HIV, annual Pap smears with referrals for abnormalities, free condoms, and risk-reduction counseling. Pregnant women were referred for antenatal care, and women who tested HIV-positive — either at screening or during the trial — were referred to existing services in the communities. The study clinics also offered onsite services to women who tested HIV-positive, such as assessment of HIV disease progression, nutritional counseling, CD-4 cell counts, and support groups. The Council provided funding to the study clinics to support the referral services, and we conducted an evaluation with participants and clinic staff at the referral centers to identify barriers the women faced in seeking care.

The randomized, double-blind study found no differences between women using Carraguard and women using the placebo in terms of safety, and gel-related side effects were minor and infrequent. The findings regarding safety and lack of side effects are important because Carraguard's favorable safety profile and physical properties make it a potentially useful vehicle for future-generation microbicides being developed by the Population Council. 